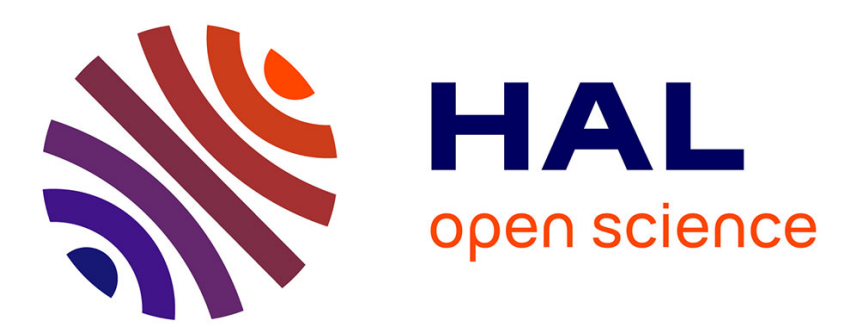

\title{
Crystal Oriented Manganese Zinc Ferrites Made from Acicular Fine Particles
}

\author{
N. Hiratsuka, K. Kakizaki, M. Sugimoto
}

\section{To cite this version:}

N. Hiratsuka, K. Kakizaki, M. Sugimoto. Crystal Oriented Manganese Zinc Ferrites Made from Acicular Fine Particles. Journal de Physique IV Proceedings, 1997, 07 (C1), pp.C1-69-C1-70. 10.1051/jp4:1997115 . jpa-00254794

\section{HAL Id: jpa-00254794 https://hal.science/jpa-00254794}

Submitted on 1 Jan 1997

HAL is a multi-disciplinary open access archive for the deposit and dissemination of scientific research documents, whether they are published or not. The documents may come from teaching and research institutions in France or abroad, or from public or private research centers.
L'archive ouverte pluridisciplinaire HAL, est destinée au dépôt et à la diffusion de documents scientifiques de niveau recherche, publiés ou non, émanant des établissements d'enseignement et de recherche français ou étrangers, des laboratoires publics ou privés. 


\title{
Crystal Oriented Manganese Zinc Ferrites Made from Acicular Fine Particles
}

\author{
N. Hiratsuka, K. Kakizaki and M. Sugimoto* \\ Department of Functional Materials Science, Faculty of Engineering, Saitama University, \\ 255 Shimo-Ohkubo, Urawa 338, Japan \\ * Department of Culture Information, Teikyo Heisei University, Uruido, Ichihara 290-01, Japan
}

\begin{abstract}
The acicular $\mathrm{Mn}-\mathrm{Zn}$ ferrite fine particles composed of $65.6 \mathrm{~mol} \% \mathrm{Fe}, 21.9 \mathrm{~mol} \% \mathrm{Mn}$ and $12.5 \mathrm{~mol} \% \mathrm{Zn}$ were made. These $\mathrm{Mn}-\mathrm{Zn}$ ferrite particles were etched in $1 \mathrm{~N}-\mathrm{HCl}$ solution for $3 \mathrm{hrs}$. The fine particle was made up of several crystallites whose long axis were $0.2-1.0 \mu \mathrm{m}$, and arranged to $\langle 311\rangle$ direction. These fine particles were pressed with applying magnetic field. The oriented $\mathrm{Mn}-\mathrm{Zn}$ ferrites were prepared by sintering at $1250^{\circ} \mathrm{C}$ for $4 \mathrm{hrs}$. in air and then cooling in nitrogen atmosphere. The oriented $\mathrm{Mn}-\mathrm{Zn}$ ferrite exhibited strong crystal orientation similar to the single crystal of it. The magnetic anisotropy constants were $\mathrm{K}_{1}=2.5 \times 10^{3} \mathrm{erg} / \mathrm{cc}$ and $\mathrm{K}_{2}=-0.2 \times$ $10^{3} \mathrm{erg} / \mathrm{cc}$ and the easy magnetization axis was $\langle 100\rangle$ direction.
\end{abstract}

\section{Introduction}

Single-crystal Mn-Zn ferrites, which have high saturation magnetization and initial permeability, are widely put into practice as high density magnetic head. However, they can't been used at high frequency of $1 \mathrm{MH} z$ or above because of low resistivity. On the other hand, polycrystalline $\mathrm{Mn}-\mathrm{Zn}$ ferrites, whose saturation magnetization and initial permeability are not good as those of single-crystal Mn-Zn ferrites, can improve magnetic characteristics at high frequency by forming high resistive boundary layers. We therefore prepare crystal oriented $\mathrm{Mn}-\mathrm{Zn}$ ferrites whose crystallites are oriented like those of single-crystal as well as form high resistivity layers at grain boundary. The reports of the crystal oriented soft ferrites were few : the $\mathrm{Mn}-\mathrm{Zn}$ ferrite was formed by using hexagonal platelet $\alpha-\mathrm{Fe}_{2} \mathrm{O}_{3}$ and $\alpha-\mathrm{MnOOH}$. [1,2] In this paper, preparation procedure, crystal orientation and magnetic properties of the crystal oriented $\mathrm{Mn}-\mathrm{Zn}$ ferrites are presented.

\section{Experimental}

The starting materials were acicular geothite $(\alpha-\mathrm{FeOOH})$, of the order of around $3.5 \mu \mathrm{m}$ long axis and aspect ratio of around 35 , as well as $\mathrm{Mn}\left(\mathrm{C}_{5} \mathrm{H}_{7} \mathrm{O}_{2}\right)_{3}$ and $\mathrm{Zn}\left(\mathrm{C}_{5} \mathrm{H}_{7} \mathrm{O}_{2}\right)_{2}$. These were weighed to compose of $65.6 \mathrm{~mol} \%$ of $\mathrm{Fe}, 21.9 \mathrm{~mol} \%$ of $\mathrm{Mn}$ and $12.5 \mathrm{~mol} \%$ of $\mathrm{Zn}$, and then well-mixed in the solvent of water and ethanol. The acicular Mn-Zn ferrite fine particles were prepared when heated at $900^{\circ} \mathrm{C}$ for 4 hrs. in nitrogen gas atmosphere. After these fine particles were dispersed in $70 \%$ of slurry concentration by using wet ball-milling method, they were pressed at $200 \mathrm{~kg} / \mathrm{cm}^{2}$ by the wet press method being applied $12 \mathrm{kOe}(960 \mathrm{kA} / \mathrm{m})$ of magnetic field. The samples which were also pressed applying no magnetic field for comparing with above-mentioned samples. The oriented $\mathrm{Mn}-\mathrm{Zn}$ ferrites were prepared when they were heated at $1250^{\circ} \mathrm{C}$ for $4 \mathrm{hrs}$. in air and then cooled in nitrogen gas atmosphere.

\section{Results and discussion}

Photo 1 shows SEM photograph of the acicular $\mathrm{Mn}-\mathrm{Zn}$ fine particles $(\mathrm{Ms}=68.8 \mathrm{emu} / \mathrm{g}$ ) having about $2 \mu \mathrm{m}$ of long axis and about 15 of aspect ratio. Photo 2 shows SEM photograph of the fine particle which was etched in $1 \mathrm{~N}-\mathrm{HCl}$ for $3 \mathrm{hrs}$. Several crystallites having $0.2-1.0 \mu \mathrm{m}$ of long axis arranged to $\langle 311\rangle$ in the parallel direction to its long axis.

Figure 1 shows a scheme of press and applied magnetic field direction for the cubic shaped $\mathrm{Mn}-\mathrm{Zn}$ ferrite. Oriented $\mathrm{Mn}-\mathrm{Zn}$ ferrite were made as follows. The pressed bodies were sintered at $1250^{\circ} \mathrm{C}$ for $4 \mathrm{hrs}$. in air and then cooled in nitrogen gas. Figure 2 shows $x$-ray diffraction patterns of the sample as shown in fig. 1 . The sample indicates intense crystal orientation : 
(311) plane in (a). (100) plane in (b) and (110) plane in (c). Figure 3 shows a torque curve of the oriented $\mathrm{Mn}-\mathrm{Zn}$ ferrite measured for (c) plane as shown in fig 1 . The curve was distorted comparing with sine wave in the vicinity of $150^{\circ}$ to $210^{\circ}$. When the curve was analyzed and calculated anisotropy constants, $\mathrm{K}_{1}$ and $\mathrm{K}_{2}$ were $2.5 \times 10^{3}$ $\mathrm{erg} / \mathrm{cc}$ and $-0.2 \times 10^{3} \mathrm{erg} / \mathrm{cc}$, respectively.

The easy magnetization axis of the oriented $\mathrm{Mn}-\mathrm{Zn}$ ferrite corresponds to $\langle 111\rangle$ direction as a result of $K_{1}>0$. Toroidal cores of the oriented $\mathrm{Mn}-\mathrm{Zn}$ ferrite bulk were prepared to investigate dependence of initial permeability on frequency. Three kinds of toroidal cores were prepared to press by wet method with applied magnetic field:sample (A) was pressed between same magnetic poles, sample (B) between different poles and sample $(C)$ without magnetic field. These were sintered by the above-mentioned process. Figure 4 shows dependence of initial permeability on frequency for the samples. The sample (A) shows the highest value of initial permeability. This is because the $\langle 100\rangle$ direction of the easy magnetization axis arranged parallel to flux. As a result of $x$-ray diffraction analysis, the crystal orientation of the sample (A), (B) and (C) arranged parallel to the $\langle 100\rangle,\langle 111\rangle$ and $\langle 110\rangle$ direction, respectively.

\section{Conclusion}

1) The acicular $\mathrm{Mn}-\mathrm{Zn}$ ferrite fine particles composed of $65.6 \mathrm{~mol} \% \mathrm{Fe}, 21.9 \mathrm{~mol} \%$ $\mathrm{Mn}$ and $12.5 \mathrm{~mol} \% \mathrm{Zn}$ were fabricated by sintering at $900^{\circ} \mathrm{C}$ for 4 hrs. in nitrogen gas atmosphere. The fine particles, of the order of $2 \mu \mathrm{m}$ long axis and 15 of aspect ratio, have $68.8 \mathrm{emu} / \mathrm{g}$ of saturation magnetization.

2) These $\mathrm{Mn}-\mathrm{Zn}$ ferrite particles were etched in $1 \mathrm{~N}-\mathrm{HCl}$ solution for $3 \mathrm{hrs}$.. The fine particle was made up of several crystallites whose long axis were $0.2-1.0 \mu \mathrm{m}$, and arranged to $\langle 311\rangle$ direction.

3) These fine particles were pressed with applying magnetic field The oriented Mn$\mathrm{Zn}$ ferrites were prepared by sintering at $1250^{\circ} \mathrm{C}$ for $4 \mathrm{hrs}$. in air and then cooling in nitrogen atmosphere

4) The oriented $\mathrm{Mn}-\mathrm{Zn}$ ferrite exhibited strong crystal orientation similar to the single crystal of $i t$. The magnetic anisotropy constants were $K_{1}=2.5 \times 10^{3} \mathrm{erg} / \mathrm{cc}$ and $\mathrm{K}_{2}=-0.2 \times 10^{3} \mathrm{erg} / \mathrm{cc}$ and the easy magnetization axis was $\langle 100\rangle$ direction.

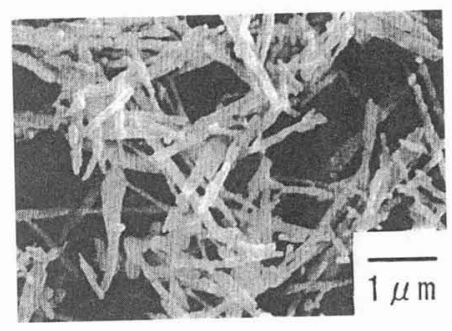

Photo.1 SEM micrograph of acicular manganese zinc ferrite particles sintered at $900^{\circ} \mathrm{C}$

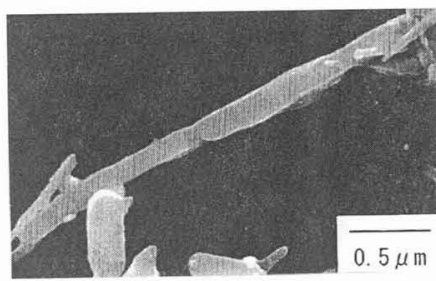

Photo. 2 SEM micrograph of chemically etched acicular manganese zinc ferrite particles.

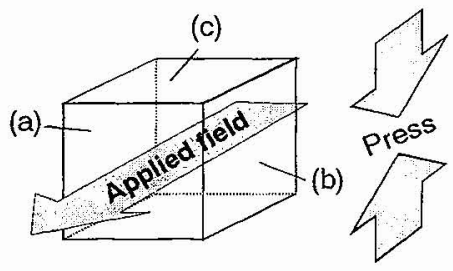

Fig. 1 Schematics of the process of making crystal-oriented $\mathrm{Mn}-\mathrm{Zn}$ ferrites.

\section{References}

[1] K.Kugimiya : IEEE Trans. Mag., 10 (1974) 907.

[2] E.Hirota : IEEE Trans. Mag., 7 (1971) 337.

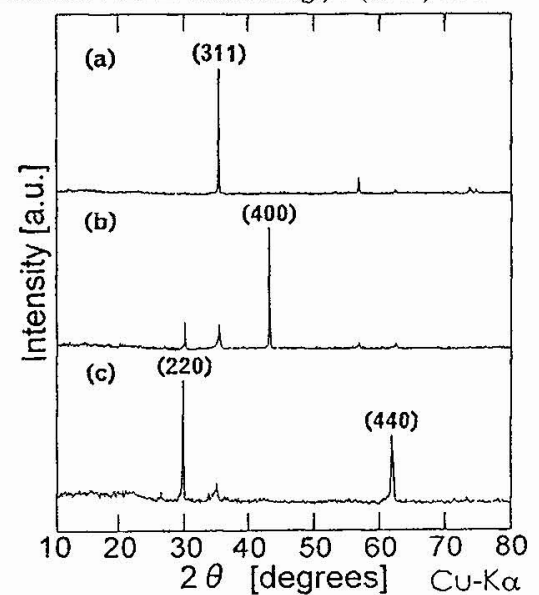

Fig.2 X-ray diffraction pattems measured in the three dimentional directions of crystal-oriented manganese zinc ferrite sintered at $1250{ }^{\circ} \mathrm{C}$.

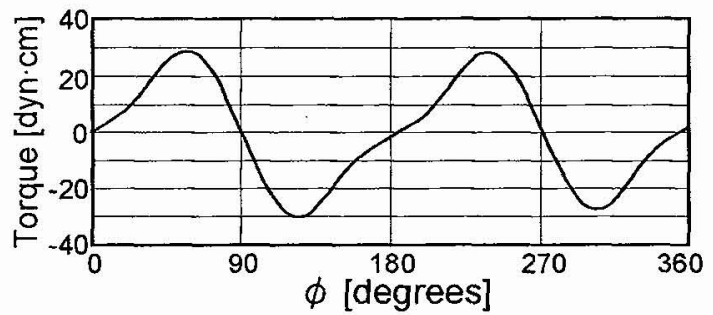

Fig.3 Magnetic torque curve of the oriented $\mathrm{Mn}-\mathrm{Zn}$ ferrite measured for (c) plane as shown in fig.1.

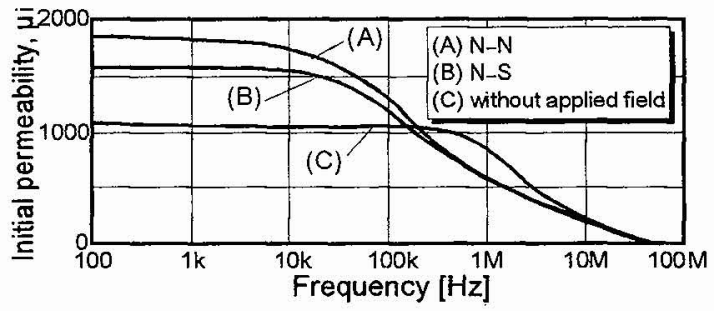

Fig.4 Dependence of initial permeability on frequency for the samples. 